\title{
Seasonal Variability of Flow and Nitrate Flux in Gilgel Gibe River, South West, Ethiopia
}

\author{
Yalemsew Adela*, Esayas Alemayehu and Tamene Adugna \\ Jimma University, Institute of Technology, School of Civil and Enviormental Engineering, Environmental Engineering Division, Ethiopia \\ *Corresponding author: Yalemsew Adela, Jimma University, Ethiopia, Tel: +251(0)911974550; E-mail: yalemsew.adela@ju.edu.et \\ Rec date: Mar 10, 2015; Acc date: May 13, 2015; Pub date: May 20, 2015
}

Copyright: (c) 2015 Yalemsew A, et al. This is an open-access article distributed under the terms of the Creative Commons Attribution License, which permits unrestricted use, distribution, and reproduction in any medium, provided the original author and source are credited.

\begin{abstract}
Nitrate is a limiting nutrient for plant growth and vital for crop production to increase agricultural productivity. However, its excessive presence in aquatic environment poses risk turning in to major aquatic ecosystem perturbation. Dissolved nitrate from lands to waterways is mainly exported via runoff and leaching. The transport of nitrate in a river is a function of the streamflow rate and its concentration, which render to the seasonal variation. Therefore, the aim of this study was to assess the seasonal variation of flow and nitrate flux. Streamflow data of the Gilgel Gibe River for the period of two years (2013-2014) were used. The baseflow is separated using Web-based Hydrograph Analysis Tool (WHAT). Dissolved nitrate concentrations measured on daily basis were also used. The effects of storm events on flow and nitrate transport were examined during dry and wet seasons. The river had shown high discharge rate from the mid June to late October. The baseflow index (BFI) was found 0.76 indicating that the streamflow is mainly controlled by groundwater discharge. Similarly, during the dry seasons, total nitrate input was considerably less than in wetter seasons. Nitrate concentrations, however, were unusually high in the first summer storm runoff after the dry season. The average annual nitrate loads varied from 13761.2 ton to 156.45 ton during the wet and dry seasons respectively. The regression curve for the nitrate load against streamflow $\left(r^{2}=0.88\right)$ has shown significant relationship $(p$-value $=0.000$ ). In the time interval studied, over $95 \%$ of the nitrate was transported from the watershed during the wet seasons of greater rainfall, which disclosed that seasonality and river flow are primary forcing functions when considering nitrate loadings in this watershed.
\end{abstract}

Keywords: Baseflow; Nitrate load; Seasonal variation; Streamflow

\section{Introduction}

The intrusion of nitrate into the water bodies has been affecting the aquatic ecosystem and even human health worldwide. The increase in nitrate concentrations in water bodies is due to natural and/or anthropogenic sources, such as intensive animal operations, waste materials, nitrate over- application of manure, irrigated and row crop agriculture, with nitrate from fertilizer-induced mineralization, septic tank systems and landfills [1]. Different studies in different catchments with various agro ecosystems have shown abrupt stream water chemistry changes during storm events [2]. During the nitrate flux estimation from a catchment, the short-term variations may be of major importance because its concentrations do not vary linearly with discharge [3]. The gradients of nitrate concentration are often erratic and depend on the intensity of rainfall and on antecedent soil moisture conditions [4], catchment characteristics and seasonality of biological processes [3]. Understanding of the processes impacting nitrate concentration changes during storms is important to develop a clear picture on both short and long term variations in nitrogen cycling in catchments. Moreover, it is crucial to develop accurate models based on its mass-balance [2]. Transport and re-distribution of nitrate in fluvial system is controlled by water discharge, which in turn is a function of climate, topographic relief, water retention properties of the soils, and geologic structure of the basin [5].

Due to the inherent behavior of nitrate, i.e., simple solubility, its mobility in different environmental compartments is at ease. Henceforth, several researches have been conducted to assess its transport mechanism and effect in aquatic system by using various methods. Now a day, hydrological and biogeochemical monitoring of catchments has become a common approach to studying water resource issues [5-8]. The nitrate concentrations usually show small year-to-year variations and marked by seasonal variations where it increases in wet seasons, when the vegetation uptake is minimal and the drainage is high. Seasonal variations are also attributed to the availability of nitrate leaching over the year [6-8]. In Gilgel Gibe catchment, the agricultural activities are highly supported with inorganic fertilizers due to the low soil fertility. According to the Jimma zone agricultural bureau, annually 5-10 tons of Urea is distributed to the farmers in this Zone. The Gilgel Gibe catchment found in this zone receives 1 to 2 tons of urea annually. Though this much amount of nitrogenous fertilizer has been consumed, there has no research output on water quality issues particularly pertaining nutrient status. The catchment comprises a hydropower reservoir which is exposed to the eutrophication phenomenon. During the environmental impact assessment phase of the hydropower project there are few measurements indicated on the report regarding to water quality parameters. Generally, the area is in precarious condition of data important to understand water quality status and nutrient transport dynamics. Therefore, the aim of this study was to assess: the seasonal variation of flow and nitrate flux, relationship between streamflow and nitrate flux and develop a regression curve for nitrate load against streamflow temporally. 


\section{Materials and Methods}

\section{Description of the watershed}

Gilgel Gibe catchment is located in the southwestern part of Ethiopia in Jimma zone, Oromia region situated within Omo-Gibe basin. The whole Gilgel gibe sub catchment which sheds water to the reservoir lies between latitude of $7^{0} 21^{\prime}$ to $7^{0} 58^{\prime} \mathrm{N}$ and longitude of $36^{0} 31^{\prime}$ to $37^{0} 26^{\prime} \mathrm{E}$ covering an area of about $4300 \mathrm{~km}^{2}$. The area is flat plateau about 1,650 $\mathrm{m}$ a.s.l and consists of a series of gentle sloping low hills and broad plains surrounded by hills or mountains. The Gilgel Gibe River, which flows from southwest to northeast, is a tributary of the Great Gibe River and is extremely variable in the course and gradient. The Gilgel Gibe is the main river, which creates the reservoir that covers an area of $55 \mathrm{~km} 2$. The annual rainfall of the catchments area varies from a minimum of $1,300 \mathrm{~mm}$ near the confluence with the Great Gibe River, to a maximum of about $1,800 \mathrm{~mm}$ on the mountains. Rainfall decreases throughout the catchments with a decrease in elevation. The average annual rainfall over the whole Gilgel Gibe basin where it joins the Great Gibe River is $1,527 \mathrm{~mm}$. Sixty percent of the total amount of annual rainfall occurs between June and September 30 per cent from February to May and only 10 per cent between Octobers to January [9]. The Gilgel Gibe River flow (2013-2014) at Asendabo gauging station averages $47.3 \mathrm{~m}^{3} / \mathrm{sec}$, although it can vary from 2.69 $\mathrm{m}^{3} / \mathrm{sec}$ during late winter low flow conditions to $>190 \mathrm{~m}^{3} / \mathrm{sec}$ during storm events. Typically discharge from rainfall is high in summer (June to September) and low to moderate the remainder of the year. The gentle slopes and the central plains of the foothills of the ridge is intensely cultivated and densely populated area. Small scattered settlements are widespread throughout the area with groups of tukuls distributed with varying degrees of regularity. Single tukuls are also scattered over a wide area of land. The population affected by the reservoir, buffer zone and associated construction facilities was 15,351 people belonging to 2,476 households in 4 provinces [9].

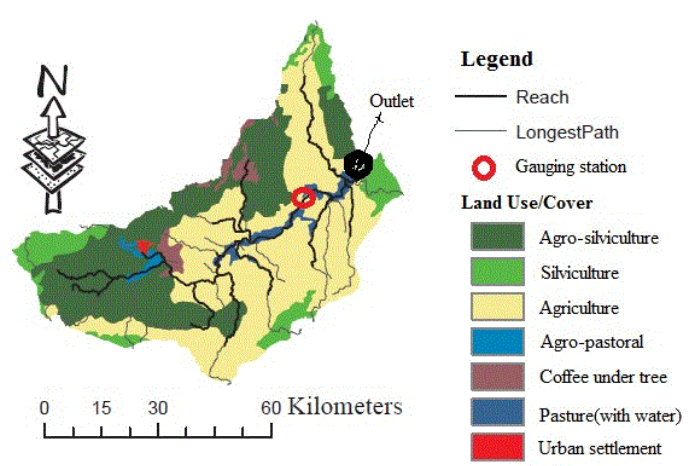

Figure 1: Gilgel Gibe watershed boundary and land use/cover map.

According to the Ethiopian ministry of water, irrigation and energy, the primary land use is agriculture (49.4\%), agrosilviculture $(33.1 \%)$ and silviculture $(10.75 \%)$ which covers around $93 \%$ of the catchment land use/land cover. The remaining is covered by coffee, agro-pastoral and open waters. The agricultural sector uses various types of fertilizers (i.e., superphosphate $\left(\mathrm{P}_{2} \mathrm{O}_{5}\right)$, Diammonum phosphate (DAP) and Urea to enhance the productivity. At the farmlands in this catchment, $46 \mathrm{~kg} / \mathrm{ha}$ of nitrogen is applied for maize, teff and soya bean cultivation. This amount is applied three times for a complete fertilization of the farm land at different time. In this catchment, there is no significant point source of nitrate $-\mathrm{N}$ pollution (Figure 1 ).

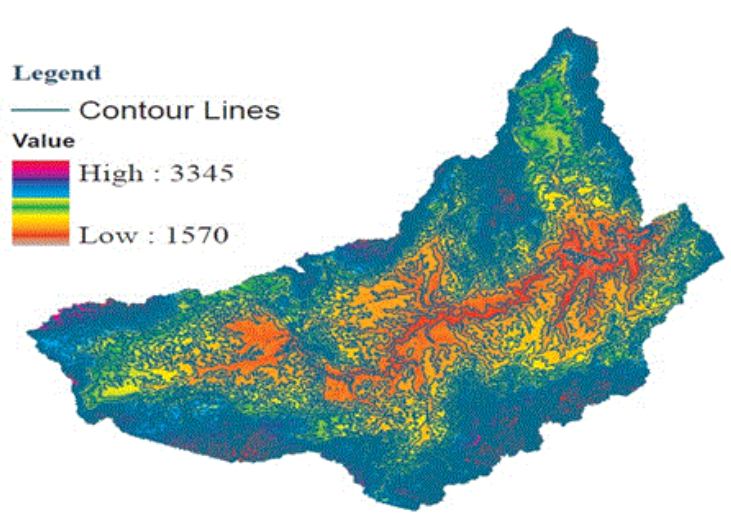

Figure 2: Digital Elevation Map.

\section{Hydrograph separation}

Baseflow was separated from the streamflow records using the Webbased Hydrograph Analysis Tool (WHAT) [10]. There are two digital filter methods available in the WHAT program: one parameter digital filter method and two-parameter digital filter parameter method (also known as the Eckhardt filter method where the Eckhardt filter was used for baseflow separation in this study. The two parameters of the Eckhardt method consist of the filter parameter and BFImax. The filter parameter describes the rate at which the streamflow decreases with time following a recharge event and can be derived by recession analysis. Daily baseflow computation with the Eckhardt filter method can be expressed as [11,12] (Figure 2).

$$
\mathrm{b}_{\mathrm{k}}=\left[\left(1-\mathrm{BFI}_{\max }\right) * \mathrm{a} * \mathrm{~b}_{\mathrm{k}-1}+(1-\mathrm{a}) * \mathrm{BFI}_{\max } * \mathrm{y}_{\mathrm{k}}\right] /\left(1-\mathrm{a} * \mathrm{BFI}_{\max }\right)
$$

Where, $b_{k}$ : Baseflow at time step $k, b_{k-1}$ : Baseflow at time step k-1, $\mathrm{y}_{\mathrm{k}}$ : Total streamflow at time step $\mathrm{k}, \mathrm{BFI}_{\max }$ : Baseflow Index (ratio of baseflow to the total flow), a: Filter parameter.

Eckhardt [12] proposed values for BFImax in Equation (1) based on various aquifer types such as perennial streams with porous aquifers, ephemeral streams with porous aquifers and perennial streams with hard rock aquifers. In this study, perennial streams with porous aquifers are considered based on hydrologic and geological characteristics [13] of the studied watersheds.

\section{Sampling and data analysis methods}

Water samples were collected daily near Asendabo stream gauge (Lat $7^{\circ} 46^{\prime} 0.81^{\prime \prime} \mathrm{N}$, Long $37^{\circ} 11^{\prime} 53.12^{\prime \prime}$ E) from August 2013 until March 2014 for nitrate concentration measurement. There were no high flows $>199 \mathrm{~m}^{3} / \mathrm{s}$ in the summer of 2013 during flood event. River flow data were obtained from the Ministry of water resource, irrigation and energy for the period of two years (2013-2014) for the Asendabo gauging station. Duplicate samples were analyzed for nitrate concentration and the results mathematically averaged. Filtered (Whatman $25 \mathrm{~mm}$ GF/F filters) water samples $(20 \mathrm{ml})$ were collected for nitrate analysis and frozen within an hour. A daily sample analysis was carried out using standard laboratory analysis for nitrate concentration. After laboratory analysis the data obtained was stored and processed using Minitab Version 16 statistical package. Descriptive 
and inferential statistics such as: simple regression, correlation analysis and nonparametric Mann-Whitney test were employed.

\section{Nitrate load calculation}

The nitrate concentration data were combined with hydrographic (river discharge) data to calculate nitrate loadings from the surrounding watershed. Nitrate loads are a product of a nitrate concentration and the mass water flow. To calculate the amount of nitrate transported by the Gilgel Gibe River in a specified time period the following formula was used:

$$
\text { Nitrate (mass, time) }=\mathrm{k} \int_{t}^{t 2} \text { flux }(\mathrm{t}) \mathrm{dt}
$$

Where flux $(t)=C(t) * Q(t)$, and $k=i s$ a constant for converting units, and $t$ is the time interval from initial time $t$ to final time $t_{2} \cdot C(t)$ represent the nitrate concentration at time $t$ and $Q(t)$ is the corresponding river flow rate. The cumulative load is estimated from $1 / 8 / 2013$ to $1 / 4 / 2014$ ( $t=0$ to $t_{2}=243$ days). The seasonal nitrate load is estimated in the time interval between the time periods for specific seasons.

\section{Result and Discussion}

\section{River flow}

River discharge during flood events of the year 2013 (summer, June 1, to September 31, 2013) and year 2014 (summer, June 1, to September 31,2014 ) peaked sharply followed by a gradual recession for eight to 12 days (Figure 3). The August 2013 and 2014 (summer) stream flow was the largest storms for their respective water years. The lowest river discharge is recorded in February (winter) for the water year 2013 and 2014. Looking into Figure 3, the seasonal variation for the discharge indicated that the Gilgel Gibe River has highest flow rate from the midsummer to end of autumn in both water years. Oppositely the lowest river flow is observed from the early beginning of winter to the mid-spring.

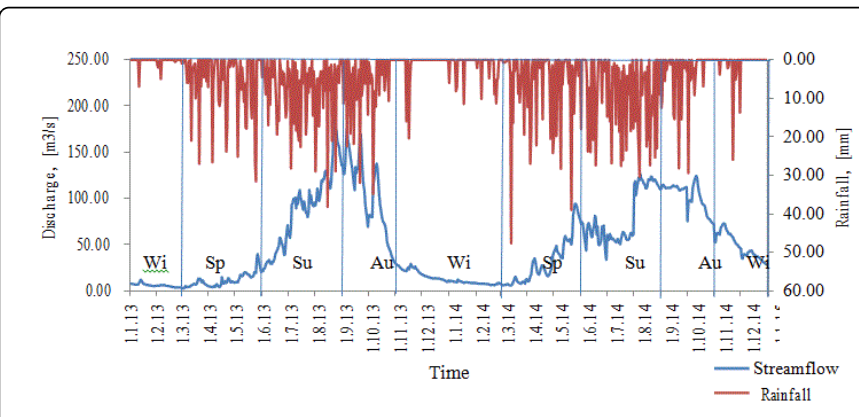

† Seasonal classes; Wi- winter, Sp-spring, Su-Summer and Au-Autumn

Figure 3: Hydrograph of Gilgel Gibe River and daily rainfall graph.

Since the river discharge is mainly from rainfall, it is good to look the relationship between rainfall and river nitrate concentration. Figure 4 shows that the peak nitrate concentration is observed at the beginning of August of the first measurement made. From Figure 3, the summer rainy season starts from June until beginning of September.

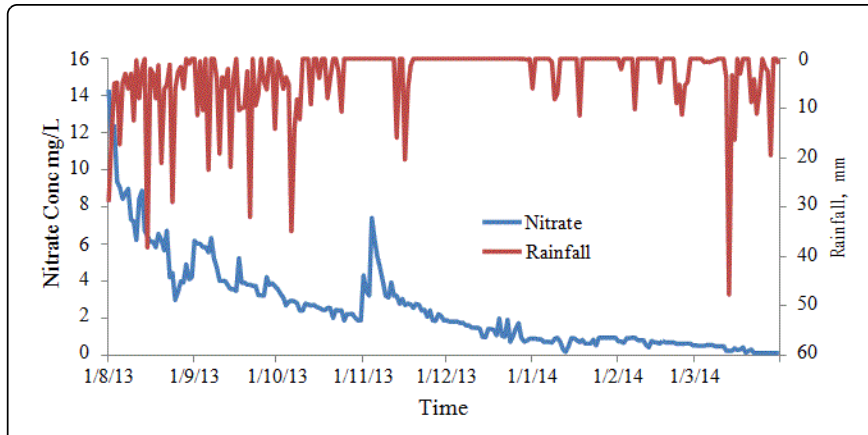

Figure 4: Rainfall versus Nitrate concentration.

Therefore, one can conclude that the highest nitrate concentrations could be observed in the wet season where the soil accumulated nitrate in the dry season of winter and spring come to be concentrated in the wet storm runoff. The Pearson correlation between these variable indicated the positive weak association $\left(\mathrm{r}^{2}=0.31\right)$ and with regression equation of: Nitrate $=2.18+0.104$ Rainfall $\left(\mathrm{R}^{2}\right.$-adjusted $\left.=9 \%\right)$.

\section{Hydrograph separation}

The baseflow component of a streamflow is basically influenced by watershed characteristics such as watershed physiographic features, distribution of water storage, evapotranspiration, geomorphology, land use, and soil types [14]. In this catchment the result (Figure 5) indicates that groundwater discharge contributed the larger water volume for the annual streamflow. Thus, default BFImax and filter parameter values of 0.80 and 0.98 describing watersheds with perennial streams and porous aquifers were used as implemented in WHAT. Using the recursive digital filter method, the basflow index (BFI) for the Gilgel Gibe river flow was 0.76. This value suggests that more than $75 \%$ of the long-term total streamflow in this catchment is possibly contributed from groundwater discharge. The Mann-Whiteny test between direct runoff and baseflow ( $\mathrm{p}$-value $=0.000$ ) also verify that the mean values are significantly different. Studies disclosed that watershed covered principally by coarse materials and natural vegetation tends to contribute high proportions of groundwater to streams [15].

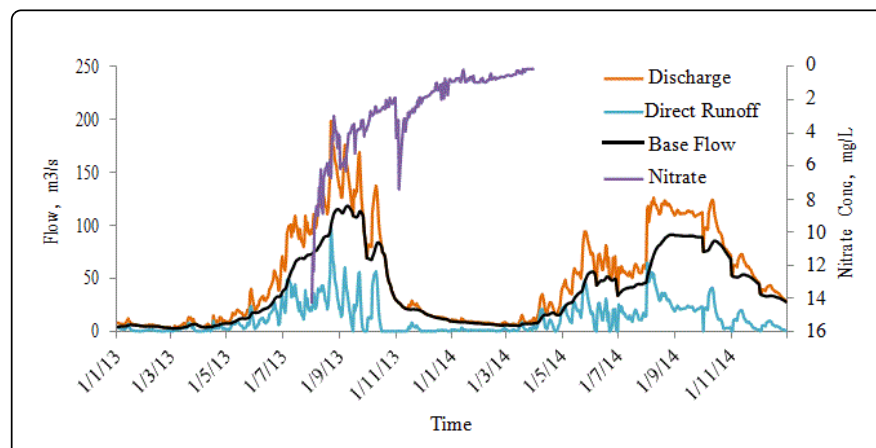

Figure 5: Hydrograph components and river nitrate concentration.

\section{River nitrate concentration}

The mean nitrate concentration in the Gilgel Gibe River measured at the gauge is $2.54 \pm 2.4 \mathrm{mg} / \mathrm{L}$. Its concentration varied by a factor of 
130 , with the lowest values coinciding with relatively low river flow during March (Figure 6). The nitrate concentration increased rapidly during high flow events and then decreased by 15 to 20 percent as the storm progressed. During the drought year 2013/14, the nitrate input was considerably less than in wetter years. The nitrate concentrations were unusually high $(14.5 \mathrm{mg} / \mathrm{L})$ in the midsummer and first autumn storm runoff after the drought. After summer and autumn high flow events, nitrate decreased smoothly. Thus in high rainfall seasons, more nitrate is transported into the river from the watershed than in low rainfall seasons [5]. The river flow and nitrate concentration have shown a positive and strong correlation $\left(\mathrm{r}^{2}=0.71\right.$, P-value $\left.=0.000\right)$ which implies that the seasonal variation of nitrate is a function of river flow fluctuation. Therefore, during storm events the higher leaching rate of nitrate from non-point source agricultural landscapes plays a vital role for the overall increment of nitrate concentration in the stream.

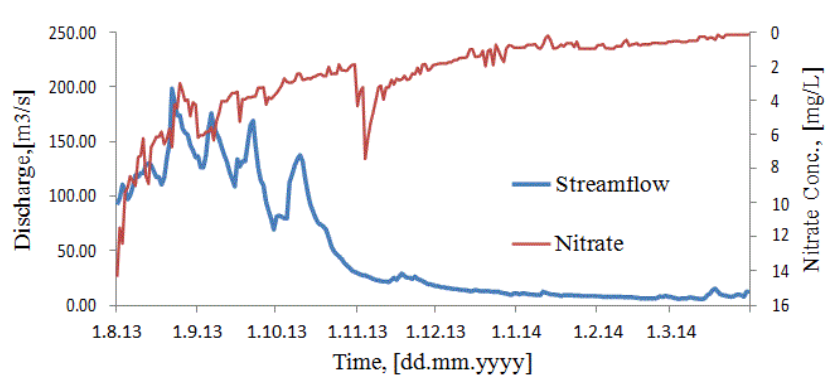

Figure 6: Nitrate concentrations against discharge.

\section{Nitrate load}

Nitrate load calculations indicate that the annual nitrate load is directly related to river flow. Thus in high rainfall seasons, more nitrate is transported into the river from the watershed than in low rainfall months. During dry seasons, nitrate tends to build up in soils, largely as a result of reduced plant uptake, and is washed into streams at larger rates during subsequent wet seasons [16]. This relationship can be observed from Figure 7 where the nitrate load in the river is higher during the storm events of the water year 2013.

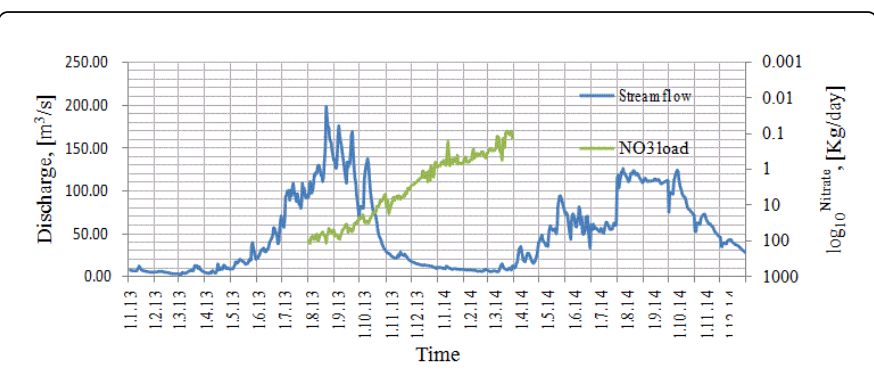

Figure 7: In-stream nitrate loads in Gilgel Gibe River.

Based on equation 1, the nitrate loads varied from $118303 \mathrm{~kg} \mathrm{day}^{-1}$ during a high-flow storm event (3/8/2013) to $83.39 \mathrm{~kg} \mathrm{day}^{-1}$ during late winter. The daily average nitrate load for the dry and wet season was $2403.98 \mathrm{~kg} \mathrm{day}^{-1}$ and $47392.73 \mathrm{~kg} \mathrm{day}^{-1}$ respectively. The average annual nitrate loads varied from 13761.2 ton $\mathrm{yr}^{-1}$ to 156.45 ton $\mathrm{yr}^{-1}$ during the wet and dry seasons respectively. For the period of August/ 2013 to September 30, 2013, the average nitrate load was 22813.3 ton, whereas for the following winter-fall period of November 1/2013 to February 28/2014, 339.4 ton and beginning of spring March 1-31/2014, 77.6 ton is predicted to have been carried down the Gilgel Gibe River. The results indicate that for the time interval studied; about $95.7 \%$ of the annual nitrate was transported during the summer months of higher rainfall. As it can be observed from Figure 8 (based on daily nitrate load and streamflow), the regression curve indicates positive and strong correlation which strengthens the above arguments.

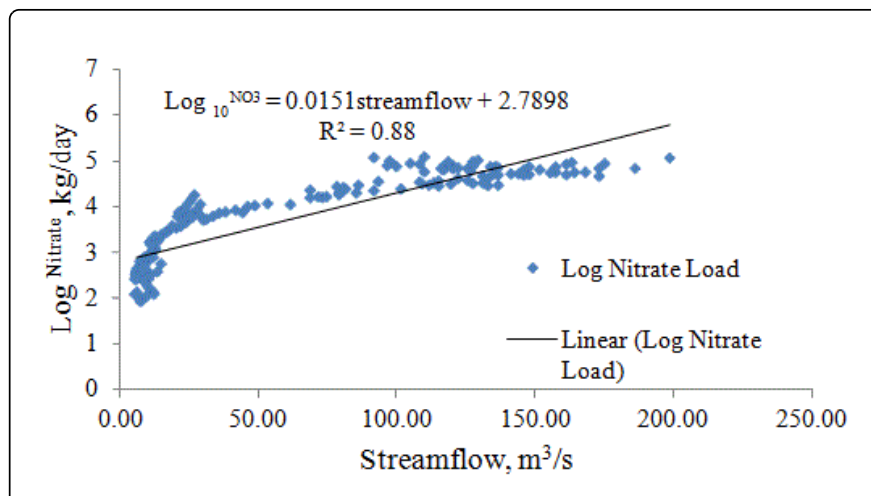

Figure 8: Log normalized nitrate load versus streamflow curve.

\section{Conclusion}

The results indicated that the streamflow increases during the storm events of wet seasons. For the overall annual streamflow the direct runoff contribution is much less than the baseflow component. This implies that the predictor parameters for the water balance in this catchment could be linked with groundwater discharge more importantly than other model parameters while calibrating watershed level hydrologic models. The higher streamflow rate is observed during summer months than other seasons. Similarly the rate of nitrate transport in the river is also dependent on storm event streamflow condition. Consequently, summer of higher rainfall will increase the annual nitrate load to the river relative to low rainfall winters. More importantly the presence of higher baseflow for the river water balance may imply the transport of nitrate in the groundwater could be significant. Generally, both nitrate and flow fluxes are highly susceptible for seasonality. Therefore, any modeling effort on the Gilgel Gibe River should address the seasonal components in the model assumptions.

\section{Acknowledgment}

The author is thankful to Jimma University for the overall support during sample collection and other facilities used for the completion of the research.

\section{References}

1. Canter LW (1997) Nitrates in groundwater.CRC Press, Lewis Publishers, London.

2. Bernal S, Butturini A, Sabater F (2002) Variability of DOC and nitrate responses to storms in a small Mediterranean forested catchment.Hydrology and Earth System Sciences 6: 1031-1041. 
Citation: Yalemsew A, Esayas A, Tamene A (2016) Seasonal Variability of Flow and Nitrate Flux in Gilgel Gibe River, South West, Ethiopia. Hydrol Current Res 7: 221. doi:10.4172/2157-7587.1000221

Page 5 of 5

3. Arheimer B, Andersson L, Lepistö A (1996) Variation of nitrogen concentration in forest streams-influences of flow, seasonality and catchment characteristics. J Hydrol 179: 281-304.

4. Biron PM, Roy AG, Courschesne F, Hendershot WH, Côté B, et al. (1999) The effects of antecedent moisture conditions on the relationship of hydrology to hydrochemistry in a small forested watershed. Hydrol Process 13: 1541-1555.

5. Sigleo A, Frick W (2007) Seasonal Variation in River Discharge and Nutrient Export to a Northeastern Pacific Estuary 73: 368-378.

6. Neill M (1989) Nitrate concentrations in river waters in the southeast of Ireland and their relationship with agricultural practice.Water Res 23: 1339-1355.

7. Johnes PJ, Burt TP (1993) Nitrate in surface waters. In: Nitrate, Processes, Patterns and Management, TP. Burt, AL. Heathwaite, ST. Trudgill (Eds.),Wiley, Chichester, UK, 269-317.

8. Reynolds B, Edwards A (1995) Factors influencing dissolved nitrogen concentrations and loadings in upland streams of the UK. Agr.Water Manage 27: 181-202.

9. Electric Light and Power Authority (1997) Gilgel Gibe hydroelectric project. environmental assessment main report. 15-20 Ethiopia.
10. Lim KJ, Engel BA, Tang Z, Choi J, Kim K, et al. (2005) Automated web GIS-based hydrograph analysis tool WHAT. J Am Water Resour Assoc 41: 1407-1416.

11. Eckhardt KA (2008) Comparison of baseflow indices, which were calculated with seven different baseflow separation methods J. Hydrol. 352: 168-173.

12. Eckhardt KA (2005) How to construct recursive digital filters for baseflow separation.Hydrol Process 19: 507-515.

13. Ethiopian Electric Power corporation (2004) Gilgel Gibe II HydroElectric project, Environmental impact assessment. Addis Ababa, Ethiopia.

14. Price K (2011) A review: Effects of watershed topography, soils, land use, and climate on baseflow hydrology in humid regions Prog Phys Geog 35: 465-492.

15. Zhang Y, Ahiablame L, Engel B, Liu J (2013) Regression Modeling of Baseflow and Baseflow Index for Michigan USA

16. Goolsby DA, Battaglin WA, Lawrence GB, Artz RS, Aulenbach BT, et al. (1999) Flux and sources of nutrients in the Mississippi- Atchafalaya River Basin. National Oceanic and Atmospheric Administration, Coastal Ocean Program Decision Analysis Series 17. Silver Spring, MD. 